\title{
TINJAUAN YURIDIS KREDIT DENGAN JAMINAN BUKU PEMILIK KENDARAAN BERMOTOR (BPKB) Studi di Koperasi Simpan Pinjam "AMANAH" Desa Sugihwaras Kecamatan Deket Lamongan
}

\author{
Oleh \\ Dhevi Nayasari Sastradinata \\ Dosen Fakultas Hukum Universitas Islam Lamongan
}

\begin{abstract}
ABSTRAK
Pertumbuhan kredit di Indonesia semakin naik. Banyak faktor yang melatarbelakangi diantaranya adalah Kebutuhan akan permodalan sampai kredit untuk memperoleh barang yang diinginkan dan kemudahan dalam memperoleh kredit. Banyak lembaga penyedia keuangan, Salah satunya koperasi, yang ada di Indonesia berlomba-lomba menarik nasabah. Dari latar belakang tersebut rumusan masalah dalam penelitian ini adalah Bagaimana proses pengajuan kredit dengan jaminan Buku Pemilik Kendaraan Bermotor (BPKB) dan apa akibat hukum yang timbul bila debitur tidak memenuhi pembayaran sesuai batas waktu yang ditentukan.

Dari hasil pembahasa dapat disimpulkan bahwa Proses pengajuan kredit dengan jaminan BPKB di Koperasi Simpan Pinjam Amanah Nasabah Mengajukan Permohonan Kredit ke Koperasi terlebih dahulu, Dari permohonan tersebut selanjutnya pihak koperasi melalukan analisa kelayakan dengan memperhatikan beberapa aspek, Apabila permohonannya disetujui maka calon nasabah harus melampirkan beberapa persyaratan sebagai kelengkapan Kredit, Setelah syarat terpenuhi, selanjutnya pihak koperasi melakukan pencairan atas pinjaman nasabah.
\end{abstract}

Akibat hukum yang timbul jika nasabah tidak bisa melakukan pembayaran sesuai batas waktu yang ditimbulkan adalah dengan dibawanya masalah ini ke pengadilan sehingga dilakukan pembatalan perjanjian dengan pihak nasabah memberikan ganti rugi yang ditimbulkan sampai dengan dipailitkan. Kedua belah pihak juga bisa memilih alternatif penyelesaian lainnya yakni negosiasi dengan jalan rescheduling atau Restrukturisasi utang. Di Koperasi Simpan Pinjam "Amanah" lebih memilih untuk negosiasi bersama dengan nasabah agar tidak menghabiskan dana banyak dan waktu jika memilih jalur persidangan.

Kata Kunci : Tinjauan Yuridis, Jaminan Buku Pemilik Kendaraan Bermotor

A. PENDAhuluan Latar Belakang Masalah

Manusia memiliki
beragam kebutuhan untuk
melangsungkan kehidupan

sehari-hari, sehingga seringkali

lupa diri saat menjalankan

aktifitas dalam rangka

memenuhi kebutuhannya.

Besarnya pendapatan sering dirasa kurang karena terjadi 
tumpang tindih antara kebutuhan dan keinginan dan hal ini lah yang menjadi masalah pada saat sekarang ini ${ }^{1}$

Kredit tidak bisa lepas dari masyarakat. Kebutuhan akan hutang dengan kemudahan untuk melunasi dengan cara angsuran menggiurkan masyarakat. Ada beberapa alasan orang mengajukan kredit. Kredit untuk modal usaha, dengan mengajukan kredit seorang yang mempunyai usaha dapat memperoleh modal, ada juga kredit untuk konsumsi, kredit untuk pembiayaan.

Setiap transaksi kredit harus mematuhi hukum yang berlaku, hal ini untuk melindungi hak-hak yang diperoleh oleh masingmasing pihak juga sebagai pondasi dari perjanjian perikatan yang mempunyai kekuatan hukum untuk melaksanakan segala kewajiban yang melekat pada setiap orang yang melakukan perjanjian.

Kredit dari sudut pandang bahasa berarti suatu kepercayaan, kepercayaan yang diberikan pihak pemberi kredit kepada penerima kredit. Penerima kredit mempunyai kepercayaan dari pemberi kredit dengan resiko mengembalikan dengan jangka waktu yang ditentukan. Pemberi kredit juga menanggung resiko apabila penerima kredit tidak menunaikan tanggung jawabnya sehingga pemberi kredit juga harus menganalisa setiap pengajuan kredit yang dilakukan.

${ }^{1}$ Natara Andri \& Nurbekti Satriyo. Solusi Cerdas Mengatasi Hutang dan Kredit. Penebar plus. Jakarta. 2008. h. 7
Dalam kredit ada 4 unsur pokok, yaitu kepercayaan, waktu, resiko dan prestasi. Kepercayaan berarti setiap pemberian kredit didasari atas kepercayaan oleh pihak pemberi kredit kepada penerima kredit untuk mengembalikan hutangnya dengan waktu yang ditentukan. $^{2}$

Waktu berarti batas antara pemberian kredit dengan pembayaran kembali oleh pihak penerima kredit dilakukan dengan jangka waktu yang ditentukan oleh kedua belah pihak. Sedangkan resiko yang dimaksud adalah setiap pemberian kredit mengandung resiko di dalamnya. Resiko ini terdapat di jangka waktu antara pemberian kredit sampai pelunasan kredit. Sehingga semakin panjang jangka waktu pelunasan semakin besar pula resiko yang didapatkan. Sedangkan prestasi adalah setiap kesepakatan yang terjadi antara pemberi kredit dan penerima kredit mengenai suatu pemberian kredit, ketika itu terjadi prestasi dan kontra prestasi. ${ }^{3}$

\section{B. METODE PENELITIAN}

Tipe penelitian ini adalah Yuridis Normatif, dengan menggunakan pendekatan perundang-undangan Oleh karena itu penelitian hukum ini difokuskan untuk mengkaji tentang norma-norma dalam hukum positif, yakni norma hukum yang terkait dengan perkreditan. Penelitian ini

\footnotetext{
${ }^{2}$ H.R. Daeng Naja. Hukum Kredit dan Bank Garasi. Citra Aditya Nakti. Bandung. 2005. h. $123-125$

${ }^{3}$ Ibid.
} 
bersifat autoritatif artinya mempunyai otoritas, bahan hukum terdiri dari Perundangundangan, catatan resmi atau risalah dalam pembuatan Perundang-undangan dan putusan hakim. adapun bahan hukum primer tersebut meliputi : Kitab Undang Undang Hukum Perdata (KUH Perdata), Undang Undang Nomor 7 Tahun 1992 tentang Perbankan sebagaimana yang telah diubah dengan Undang Undang Nomor 10 Tahun 1998, Undang Undang Nomor 10 Tahun 1998 tentang Perbankan, Undang Undang Nomor 17 Tahun 2012 tentang Perkoperasian.

Baik bahan hukum primer maupun sekunder dikumpulkan berdasarkan topic permasalahan yang dirumuskan dan diklasifikasi menurut sumber untuk dikaji secara komprehensif. Adapun bahan hukum yang diperoleh dalam penelitian adalah studi kepustakaan, aturan perundangundangan, yang penulis uraikan dan dihubungkan sedemikan rupa, sehingga disajikan dalam penulisan yang lebih sistematis guna menjawab perumusan masalah yang dirumuskaan dan dilakukan secara deduktif yakni menarik kesimpulan dari suatu permasalahan yang bersifat umum terhadap permasalahan kongkrit yang dihadapi.

\section{HASIL PENELITIAN DAN PEMBAHASAN}

\section{Tinjauan Yuridis Kredit dengan jaminan BPKB di Koperasi}

Perjanjian pada umumnya dibuat dengan maksud dan tujuan yang beraneka macam, salah satu tujuan tersebut berkaitan dengan pemberian atau permintaan kredit, istilah kredit dikenal dalam bahasa yunani "credre" yang berarti percaya atau to believe atau to trust. ${ }^{4}$ Oleh sebab itu dasar dari kredit itu adalah kepercayaan. Maksud kepercayaan bagi si pemberi kredit adalah ia percaya kepada si penerima kredit bahwa kredit yang disalurkannya pasti dikembalikannya sesuai dengan perjanjian. Sedangkan bagi si penerima kredit yang merupakan penerima kepercayaan mempunyai kewajiban untuk membayar sesuai dengan jangka waktu yang telah disepakati.

Kredit menurut Pasal 1 Angka 11 Undang-Undang Nomor 10 Tahun 1998 tentang perbankan dan selanjutnya disebut dengan Undang-Undang Perbankan menyatakan: Kredit adalah penyediaan dana atau tagihan yang dapat dipersamakan dengan itu, berdasarkan persetujuan atau kesepakatan

\footnotetext{
${ }^{4} \mathrm{H}$. Mho. Tjoekam. Perkrediatan Bisnis Inti Bank Komersial (Konsep teknik dan Kasus). Gramedia Pustaka Utama. Jakarta. 1999. h. 12.
} 
pinjam meminjam antara bank dengan pihak lain yang mewajibkan pihak peminjam untuk melunasi hutangnya setelah jangka waktu dengan pemberian bunga.

Peraturan perundangundangan yang mengatur tentang perjanjian kredit dapat dilihat dan dibaca dalam berbagai peraturan perundang-undangan, antara lain:

a. Undang-Undang Nomor 7 tahun 1992 tentang Perbankan.

b. Undang-Undang Nomor $10 \quad 1998 \quad$ tentang Perubahan UndangUndang Nomor 7 tahun 1992 tentang Perbankan;

c. Undang-Undang Nomor 23 Tahun 1999 tentang Bank Indonesia;

d. Undang-Undang Republik Indonesia Nomor 3 Tahun 2004 tentang perubahan atas Undang-Undang Nomor 23 Tahun 1999 tentang Bank Indonesia; ${ }^{5}$ Adapun tujuan pemberian kredit yang lainnya adalah:

a. Bagi kreditur

1) Pemberian kredit merupakan sumber utama pendapatan.

2) Pemberian kredit merupakan

${ }^{5} \mathrm{H}$. Salim HS. Perkembangan Hukum Kontrak Diluar KUH Perdata. PT Raja Grafindo Persada. Jakarta. 2006. h. 78-81. perangsang produkproduk lainnya

3) Perkreditan merupakan instrumen penjaga likuidasi, solvabilitas, dan profitabilitas.

b. Bagi debitur

1) Kredit berfungsi sebagai sarana untuk membuat kegiatan usaha makin lancar dan performance (kinerja) usaha semakin baik dari pada sebelumnya.

2) Memperluas kesempatan berusaha dan bekerja dalam perusahaan.

c. Bagi masyarakat

1) Kredit mengurangi pengguguran, karena membuka peluang berusaha, bekerja dan pemerataan pendapatan.

2) Kredit meningkatkan fungsi pasar karena adanya peningkatan daya beli. ${ }^{6}$

Sedangkan kredit sendiri mempunyai fungsi, sebagai berikut:

a. Untuk meningkatkan daya guna uang, apabila uang disimpan saja tidak akan menghasilkan sesuatu yang berguna, dengan pemberian kredit uang tersebut untuk menghasilkan barang dan jasa oleh penerima kredit.

b. Untuk meningkatkan peredaran dan lalu lintas

${ }^{6}$ Thomas Suyatno. Op.cit. h. 15 
uang, dengan pemberian kredit uang itu akan beredar dari wilayah yang satu ke wilayah yang lain.

c. Untuk meningkatkan daya guna barang, dengan pemberian kredit kepada debitur dapat digunakan untuk mengelola barang yang tadinya tidak berguna menjadi berguna dan bermanfaat.

d. Meningkatkan peredaran barang, kredit dapat pula menambah atau memperlancar arus barang dari satu wilayah ke wilayah yang lainnya.

e. Sebagai alat stabilitas ekonomi, dengan adanya kredit yang diberikan akan menambah jumlah barang yang diperlukan oleh masyarakat

f. Untuk meningkatkan kegairahan berusaha. ${ }^{7}$

Adapun tujuan pemberian kredit yang lainnya adalah:

d. Bagi kreditur

1) Pemberian kredit merupakan sumber utama pendapatan.

2) Pemberian kredit merupakan perangsang produkproduk lainnya

3) Perkreditan merupakan instrumen penjaga likuidasi, solvabilitas, dan profitabilitas.

e. Bagi debitur

7 Kasmir. Bank dan Lembaga Keungan Lainnya. Rajawali Pers. Jakarta. 2003. h. 97
1) Kredit berfungsi sebagai sarana untuk membuat kegiatan usaha makin lancar dan performance (kinerja) usaha semakin baik dari pada sebelumnya.

2) Memperluas kesempatan berusaha dan bekerja dalam perusahaan.

f. Bagi masyarakat

1) Kredit mengurangi pengguguran, karena membuka peluang berusaha, bekerja dan pemerataan pendapatan.

2) Kredit meningkatkan fungsi pasar karena adanya peningkatan daya beli. ${ }^{8}$

Sedangkan kredit sendiri mempunyai fungsi, sebagai berikut:

g. Untuk meningkatkan daya guna uang, apabila uang disimpan saja tidak akan menghasilkan sesuatu yang berguna, dengan pemberian kredit uang tersebut untuk menghasilkan barang dan jasa oleh penerima kredit.

h. Untuk meningkatkan peredaran dan lalu lintas uang, dengan pemberian kredit uang itu akan beredar dari wilayah yang satu ke wilayah yang lain.

i. Untuk meningkatkan daya guna barang, dengan pemberian kredit kepada debitur dapat digunakan

${ }^{8}$ Thomas Suyatno. Op.cit. h. 15 
untuk mengelola barang yang tadinya tidak berguna menjadi berguna dan bermanfaat.

j. Meningkatkan peredaran barang, kredit dapat pula menambah atau memperlancar arus barang dari satu wilayah ke wilayah yang lainnya.

k. Sebagai alat stabilitas ekonomi, dengan adanya kredit yang diberikan akan menambah jumlah barang yang diperlukan oleh masyarakat

1. Untuk meningkatkan kegairahan berusaha. ${ }^{9}$

Pengaturan umum tentang jaminan diatur dalam ketentuan Pasal 1131 KUH Perdata, dimana ditentukan bahwa segala kebendaan pihak yang berhutang (debitur) baik yang bergerak maupun yang tidak bergerak, baik yang sudah ada maupun yang baru akan ada di kemudian hari menjadi tanggungan untuk segala perikatan perorangan.

Jaminan menurut Undang-Undang Perbankan adalah "keyakinan akan itikad dan kemampuan serta kesanggupan nasabah debitur untuk melunasi hutangnya atau mengembalikan pembiayaan dimaksud sesuai dengan yang diperjanjikan."10

Landasan dan asas koperasi terdapat di dalam UURI Nomor 17 Tahun 2012 tentang perubahan atas Undang-Undang Nomor 25 Tahun 1992 tentang Perkoperasian Pasal 2

9 Kasmir. Bank dan Lembaga Keungan Lainnya. Rajawali Pers. Jakarta. 2003. h. 97

10 Rachmdi Usman. Aspek-Aspek Hukum Perbankan Di Indonesia. Gramedia Pustaka Utama. Jakarta. 2001. h. 22. dan pasal 3 dikatakan bahwa: "koperasi berlandaskan pancasila dan undang-undang dasar 1945, koperasi berdasar atas asas kekeluargaan". dari bunyi Pasal 2 itu jelas bahwa koperasi berlandaskan pancasila dan UUD 1945. UUD 1945 sebagai landasan koperasi juga ditegaskan dalam batang tubuh pasal 33 ayat 1 beserta penjelasannya, disitu dijelaskan secara eksplisit bahwa bangunan perusahaan yang sesuai dengan Pasal 1 adalah koperasi. Sedangkan asas koperasi sesuai dengan Pasal 3 UU No. 17 Tahun 2012 adalah berasaskan kekeluargaan, asas ini sesuai dengan jiwa dan kepribadian bangsa Indonesia. Koperasi sebagia suatu usaha bersama harus mencerminkan ketentuan-ketentuan sebagaimana dalam kehidupan keluarga. Dalam suatu keluarga, seagala sesuatu yang dikerjakan secara bersama-sama ditujukan untuk kepentingan bersama seluruh anggota keluarga, usaha bersama berdasarkan asas kekeluargaan ini biasanya disebut dengan gotong-royong. ${ }^{11}$

Sebagaimana yang tercantum dalam UU RI No. 17 Tahun 2012 pasal 26 ayat 1 bahwa "anggota koperasi merupakan pemilik sekaligus pengguna jasa koperasi”,"12 memberikan arti bahwa Koperasi berbeda dengan badan usaha komersial pada umumnya, Karakteristik utama koperasi yang membedakannya dengan badan usaha lain adalah bahwa anggota koperasi memiliki identitas ganda

\footnotetext{
${ }^{11}$ Ibid, h. 42.

${ }^{12}$ Undang-undang Perkoperasian 2012 dihimpun oleh Redaksi Sinar Grafika. Sinar Grafika. Jakarta. 2013. h. 18
} 
(the dual identity of the member), yaitu anggota sebagai pemilik dan sekaligus sebagai pengguna jasa koperasi (user own oriented frim),

\section{Proses Pengajuan Kredit}

Setiap calon nasabah yang akan melakukan pinjaman pada Koperasi Simpan Pinjam "Amanah" terlebih dahulu akan mengajukan permohonan. Setelah mengajukan permohonan pihak koperasi akan melakukan verifikasi. ${ }^{13}$

Adapun hak dari Koperasi Simpan Pinjam "Amanah" dapat dilihat dalam surat perjanjian kredit, hal itu diatur dalam Pasal 5, Surat Perjanjian yang berisikan :

"Debitur dengan ini menyatakan persetujuannya apabila terjadi keterlambatan dalam pembayaran kewajiban bunga dan atau angsuran pokok apabila dalam batasan waktu berlakunya kredit ini belum melunasi secara seksama dan sepatutnya seluruh jumlah kredit berikut bunga dan biaya-biaya lain yang timbul berdasarkan perjanjian ini, maka kreditur berhak memperhitungkan denda (penalty overdue) terhadap debitur sebesar $4 \%$ (empat persen) setiap bulan dari seluruh kewajiban debitur kepada kreditur yang tertunda dan dihitung secara harian."14

Berdasarkan surat perjanjian diatas, dapat dipahami bahwa apabila terjadi keterlambatan oleh debitur untuk membayar kewajibannya,

\footnotetext{
${ }^{13}$ Wawancara dengan Bapak Zainal Arifin, Nasabah Koperasi simpan pinjam "Amanah"

${ }^{14}$ Dokumentasi surat perjanjian kredit di Koperasi simpan pinjam "Amanah"
}

maka kreditur berhak memperhitungkan denda yang akan dibebankan setiap bulannya dari seluruh kewajiban debitur. Denda yang dibebankan kepada debitur merupakan akibat dari keterlambatan debitur itu sendiri.

Adapun kewajiban-kewajiban yang dimiliki oleh Koperasi Simpan Pinjam "Amanah" yang dipedomani pada Surat Perjanjian Kredit dapat dilihat dari berbagai pasal yang ada dalam surat perjanjian tersebut, salah satunya terdapat pada Pasal 1 Surat Perjanjian Kredit yang berisikan :

"Kreditur telah memberikan debitur pinjaman uang berupa fasilitas kredit modal kerja yakni kredit komersil sesuai dangan nilai pinjaman dan debitur menyatakan mengaku dan menerima pinjaman uang tersebut akan digunakan untuk menambah modal kerja, bunga dan biaya-biaya lainnya yang timbul berdasarkan perjanjian ini, untuk selannjutnya disebut pinjaman."15

Ketika debitur telah menandatangani perjanjian maka pemberian dana dengan segera diberikan oleh Koperasi Simpan Pinjam "Amanah". Kewajiban dari Koperasi Simpan Pinjam "Amanah" yakni memberikan pinjaman uang berupa fasilitas modal kerja yaitu kredit komersil yang harus digunakan sebagai modal kerja sesuai dengan perjanjian yang ditandatangani kedua belah pihak. Hal ini dilakukan oleh Koperasi 12 Pasal 5 Surat

${ }^{15} \mathrm{Ibid}$ 
Perjanjian Kredit pada Koperasi Simpan Pinjam "Amanah".

Kewajiban dari debitur dalam pelaksanaan pemberian pinjaman ini diatur dalam pasal 1763 KUHPerdata. Menurut pasal tersebut siapa yang menerima pinjaman sesuatu, diwajibkan mengembalikannya dalam jumlah dan keadaan yang sama, dan pada waktu yang ditentukan. ${ }^{16}$ Menurut pasal 1764 KUHPerdata yang menjelaskan bahwa si peminjam tidak mampu mengembalikan barang yang dipinjamnya dalam jumlah dan keadaan yang sama, maka dia diwajibkan membayar harganya dalam hal mana harus diperhatikan waktu dan tempat dimana harganya, menurut perjanjian harus dikembalikan. Jika waktu dan tempat ini tidak telah ditetapkan, harus diambil harga barang pada waktu dan tempat dimana pinjaman telah terjadi. ${ }^{17}$

\section{Akibat Hukum bagi Debitur yang Tidak melaksanakan \\ kewajibannya}

Dalam hukum perjanjian masing-masing pihak mempunyai prestasi yang bertalian erat satu dengan yang lain. Apabila salah satu pihak tidak dapat memenuhi kewajibannya

${ }^{16}$ R. Subekti \& R. Tjitrosudibio, op.cit., h. 452

${ }^{17}$ R. Subekti, op.cit, h. 128 maka perjanjian bisa dibatalkan dan menimbulkan resiko terhadap kedua belah pihak. Pembatalan perjanjian bisa dilaksanakan oleh pihak kreditur jika pihak debitur lalai dalam melaksanakan kewajibannya. Akibat dari hapusnya perikatan, masingmasing pihak tidak perlu lagi memenuhi prestasi. Pihak yang mengajukan pembatalan berhak menuntut ganti rugi sebagai akibat daripada ingkar janji dan pembatalan. ${ }^{18}$

Dalam setiap kredit ada kalanya pihak debitur tidak melaksanakan kewajibannya untuk melunasi hutang yang ada pada dirinya sehingga menimbulkan akibat hukum pada dirinya. Ada beberapa penyebab terjadi kredit bermasalah, penyebabnya dapat diklasifikasi dalam beberapa faktor:

1. Faktor intern kreditur

a. Naluri bisnis dan kemampuan menganalisa kredit yang belum memadai.

b. Para anggota komite pemutus kredit tidak memiliki integritas yang baik.

c. Pengawasan terhadap penggunaan kredit tidak memadai

d. Pemberian kredit tidak cukup atau berlebihan jumlahnya jika dibandingkan
${ }^{18}$ R. Setiawan. Pokok-pokok Hukum Perikatan. Binacipta. Bandung. h. 65-67 
dengan kebutuhan sesungguhnya

e. Tidak mempunyai informasi yang cukup tentang watak dan track record debitur

2. Faktor intern debitur
a. Penyalah gunaan
kredit oleh debitur, pemberian kredit tidak digunakan
sebagaimana tujuan kredit
b. Terjadi masalah intern dalam perusahaan yang diberi kredit
c. Tidak adanya tenaga ahli perusahaan sehingga kinerja perusahaan tidak efisien

3. Faktor ekstern

a. Kondisi perekonomian Indonesia sejak tahun 1997 mengakibatkan dampak negatif terhadap kinerja perusahaan terutama perusahaan yang pembiayaannya mengandalkan hutang.

b. Turunnya daya beli masyarakat untuk mengkonsumsi produk dan jasa yang dihasilkan oleh perusahaan sehingga perusahaan tidak mempunyai biaya yang cukup untuk menutupi produksi dan modal. c. Tingkat pengembalian investasi yang rendah. ${ }^{19}$

Apabila debitur tidak melaksanakan kewajibannya maka pihak debitur mendapatkan akibat hukum yang ditempuh oleh pihak kreditur. Pada dasarnya penyelesaian kredit macet dilakukan dengan dua cara, litigasi dan negosiasi. Tetapi kenyataan di lapangan selain kedua cara itu pihak pemberi kredit menggunakan jasa Dept Collector untuk menagih kredit meski badan jasa itu tidak memiliki wewenang untuk melakukannya. $^{20}$

a. Litigasi

Penyelesaian kredit bermasalah dengan cara litigasi adalah dengan mendayagunakan lembaga peradilan yang ada. Lembaga peradilan masih dibutuhkan oleh seseorang karena lembaga peradilan menjadi tempat yang dapat diandalkan. Penyelesaian masalah dengan litigasi ini dilakukan terhadap debitur yang usahanya masih berjalan ataupun terhadap debitur yang usahanya tidak berjalan. Ada beberapa peran yang menguatkan lembaga peradilan di masyarakat, sebagai berikut:

1) Peradilan sebagai kutup penekan atau pressure valve atas segala pelanggaran hukum,

\footnotetext{
${ }^{19}$ Suharnoko. Hukum Perjanjian Teori dan Analisa Kasus. Prenamedia Group. Jakarta. h. 76-77

${ }^{20}$ H.R. Daeng Naja. Hukum Kredit dan Bank Garasi. Citra Aditya Nakti. Bandung. 2005. h. 334-335
} 
ketertiban masyarakat, dan pelanggaran ketertiban umum

2) Peradilan diharapkan masih sebagai last resort atau tempat terakhir mencari kebenaran dan keadilan sebagaimana fungsi yang melekat padanya, penegak kebenaran dan keadilan. ${ }^{21}$

Pada prakteknya penyelesaian kredit dengan litigasi ini dilakukan dengan pengajuan gugatan atau langsung eksekusi kepada lembaga Peradilan Negeri, Pengadilan Niaga, dan Panitia Urusan Piutang Negara (PUPN).

1) Peradilan Negeri

Penanganan perkara kredit bermasalah di Pengadilan Negeri dapat ditempuh dengan beberapa cara, melalui gugatan biasa dan permohonan eksekusi grosse akta.

a) Gugatan biasa

Untuk mencapai suatu eksekusi atas putusan hakim dalam proses gugatan biasa diperlukan tiga tingkatan peradilan, yaitu Tingkat Pertama/Pengadilan Negeri, Tingkat Banding/Pengadilan Tinggi, dan Tingkat Kasasi/Mahkama Agung. Proses perkara perdata di Pengadilan Negeri dilakukan secara terbuka dengan diawali masing-masing pihak memberi alasannya. Sampai terakhir setelah mendengarkan penjelasan dan tanya jawab berbagai pihak pengadilan menjatuhkan putusan disertai dengan alasan-alasan putusan yang dijadikan dasar mengadili

b) Permohonan eksekusi grosse akta

${ }^{21}$ Ibid. h. 336
Permohonan eksekusi ini dilakukan atas dasar dan kekuatan Grosse Akta Pengakuan Hutang dan Grosse Akta Hipotik. Saat pengajuan gugatan eksekusi pihak pengadilan selalu mengacu pada jangka waktu kredit. Jika sudah jatuh tempo, maka dapat dilakukan eksekusi atau gugatan jika belum jatuh tempo maka pihak pengadilan tidak akan menerima gugatan. ${ }^{22}$

2) Pengadilan Niaga

Penyelesaian melalui Peradilan Niaga merupakan salah satu alternatif yang dapat digunakan oleh pihak kreditur terhadap debitur yang bermasalah dengan berpedoman bahwa pihak kreditur menyatakan bahwa pihak kreditur mengalami pailit. ${ }^{23}$

3) Panitia Urusan Piutang Negara Panitia urusan piutang negara (PUPN) melakukan penyelesaian kredit macet pada instansi pemerintahan, badanbadang negara, serta BUMN/D Perbankan atau Non-Perbankan. Tugas dari Panitia urusan Piutang Negara adalah mengurusi piutang yang besarnya telah pasti menurut hukum. Tetapi debitur tidak melunasi sebagaimana mestinya. Yang dimaksud dengan piutang negara adalah jumlah uang yang wajib dibayarkan kepada negara atau badan-badan yang dikuasai oleh negara. ${ }^{24}$

\section{PENUTUP}

\footnotetext{
${ }^{22}$ Ibid. h. 336-339

${ }^{23}$ Ibid. h. 340

${ }^{24}$ Ibid. h. 344-345
} 
1. Proses pengajuan kredit dengan jaminan BPKB di Koperasi Simpan Pinjam Amanah adalah sebagai berikut:

b. Nasabah Mengajukan Permohonan Kredit ke Koperasi.

c. Dari permohonan tersebut selanjutnya pihak koperasi melalukan analisa kelayakan dengan memperhatikan beberapa aspek.

d. Apabila permohonannya disetujui maka calon nasabah harus melampirkan beberapa persyaratan sebagai kelengkapan Kredit.

e. Setelah syarat terpenuhi, selanjutnya pihak koperasi melakukan pencairan atas pinjaman nasabah.

1. Akibat hukum yang timbul jika nasabah tidak bisa melakukan pembayaran sesuai batas waktu yang ditimbulkan adalah dengan dibawanya masalah ini ke pengadilan sehingga dilakukan pembatalan perjanjian dengan pihak nasabah memberikan ganti rugi yang ditimbulkan sampai dengan dipailitkan. Kedua belah pihak juga bisa memilih alternatif penyelesaian lainnya yakni negosiasi dengan jalan rescheduling atau Restrukturisasi utang. Di Koperasi Simpan Pinjam "Amanah" lebih memilih untuk negosiasi bersama dengan nasabah agar tidak menghabiskan dana banyak dan waktu jika memilih jalur persidangan. Apabila ada nasabah yang tidak memenuhi kewajibannya maka pihak koperasi akan mendatangi nasabah dan memberikan surat peringatan, diberlakukan denda keterlambatan, hingga penyitaan jaminan agar dibeli sendiri atau dilelang kepada orang lain.

\section{E. DAFTAR PUSTAKA}

H. Mho. Tjoekam. Perkrediatan Bisnis Inti Bank Komersial (Konsep teknik dan Kasus). Gramedia Pustaka Utama. Jakarta. 1999.

H. Salim HS. Perkembangan Hukum Kontrak Diluar KUH Perdata. PT Raja Grafindo Persada. Jakarta. 2006.

H.R. Daeng Naja. Hukum Kredit dan Bank Garasi. Citra Aditya Nakti. Bandung. 2005.

Kasmir. Bank dan Lembaga Keungan Lainnya. Rajawali Pers. Jakarta. 2003.

Natara Andri \& Nurbekti Satriyo. Solusi Cerdas Mengatasi Hutang dan Kredit. Penebar plus. Jakarta. 2008

R. Setiawan. Pokok-pokok Hukum Perikatan. Binacipta. Bandung. 
Rachmdi Usman. Aspek-Aspek

Hukum Perbankan Di

Indonesia. Gramedia

Pustaka Utama. Jakarta.

2001.

Suharnoko. Hukum Perjanjian

Teori dan Analisa Kasus.

Prenamedia Group.

Jakarta.

Undang-undang Perkoperasian

2012 dihimpun oleh

Redaksi Sinar Grafika.

Sinar Grafika. Jakarta.

2013. 